Huchon, P., Taylor, B., and Klaus, A. (Eds.)

Proceedings of the Ocean Drilling Program, Scientific Results Volume 180

\section{Data Report: Trace Element AND ISOTOPIC COMPOSITION OF INTERSTITIAL WATER AND SEDIMENTS FROM THE WOODLARK RISE, ODP LEG $180^{1}$}

Eric Heinen De Carlo, ${ }^{2}$ Klas K. Lackschewitz, ${ }^{3}$ and Rebecca Carmody ${ }^{4}$
${ }^{1}$ De Carlo, E.H., Lackschewitz, K.K., and Carmody, R., 2001. Data report: Trace element and isotopic composition of interstitial water and sediments from the Woodlark Rise, ODP Leg 180. In Huchon, P., Taylor, B., and Klaus, A. (Eds.), Proc. ODP, Sci. Results, 180, 1-20 [Online]. Available from World Wide Web: <http://www-odp.tamu.edu/ publications/180_SR/VOLUME/ CHAPTERS/160.PDF>. [Cited YYYYMM-DD]

${ }^{2}$ Department of Oceanography, SOEST, University of Hawaii at Manoa, Honolulu HI 96822, USA. edecarlo@soest.hawaii.edu

${ }^{3}$ Fachgebiet Petrologie der Ozeankruste, Fachbereich 5, Geowissenschaften Postfach 330 440, 28334 Bremen, Federal Republic of Germany.

${ }^{4}$ SOEST, University of Hawaii at Manoa, Honolulu HI 96822, USA.

Initial receipt: 14 December 2000 Acceptance: 7 July 2001

Web publication: 2 November 2001

Ms 180SR-160 
variability of tectonic activity in the area, was drilled on the Woodlark Rise.

In this paper we present results of isotopic $\left({ }^{87} \mathrm{Sr} /{ }^{86} \mathrm{Sr}\right.$ and $\left.\delta^{18} \mathrm{O}\right)$ and trace element ( $\mathrm{Rb}$ and $\mathrm{Ba}$ ) analyses in interstitial water (IW) from the three sites and the trace element composition and mineralogy of corresponding sediments at Site 1109. A subset of squeeze cakes remaining after IW was recovered from whole-round cores collected at Site 1109 was selected on the basis of volcanic matter content. The clays were analyzed for their trace element content to evaluate how the presence and alteration of volcanic minerals impact the chemical composition of the IW.

Volcanic matter in sediments of the Woodlark Rise is present as discrete ash layers and dispersed volcaniclastic sand, as well as large-body intrusions or basement igneous rocks deep in the holes (Taylor, Huchon, Klaus, et al., 1999). Sediments cored at Site 1109 record progressive subsidence from subaerial to lagoonal then shallow- to deepwater marine settings between the latest Miocene ( $~ 8 \mathrm{Ma})$ and the late Pleistocene. The hemipelagic Pliocene sediments (i.e., the upper $~ 550$ meters below seafloor [mbsf]) include an abundance of volcanic ash layers and dispersed volcanic material, much of which is quite fresh and unaltered (Taylor, Huchon, Klaus, et al., 1999). Interpretations of the data reported here will be presented elsewhere (De Carlo et al., unpubl. data).

\section{METHODS}

High-resolution sampling at Sites 1109 and 1115 successfully recovered IW from whole rounds taken from nearly every recovered sedimentary core in each hole. At Site 1118 where the first 200 mbsf was drilled without coring, a lower-resolution sampling program was undertaken with whole rounds collected every second or third core beginning near 250 mbsf. The suite of 26 IW samples obtained at Site 1118 complements the more than 130 IW samples collected from Sites 1109 and 1115.

Methods for recovery of IW and details of the sample handling and shipboard analyses are described in Taylor, Huchon, Klaus, et al. (1999) and are only briefly described here. IW was recovered by mechanical squeezing of 5 - to $15-\mathrm{cm}$ whole-round cores in a titanium squeezer, modified after the standard ODP stainless steel squeezer of Manheim and Sayles (1974), to provide contamination-free IW samples. Samples were initially collected from the squeezer through $0.45-\mu \mathrm{m}$ Gelman polysulfone disposable filters into scrupulously cleaned $50-\mathrm{mL}$ plastic syringes. IW to be used for trace element analysis was filtered through acid-washed 0.2- $\mu \mathrm{m}$ Gelman polysulfone disposable filters, transferred to acid-washed high-density polyethylene bottles, acidified with $50 \mu \mathrm{L}$ of ultra-high purity $\mathrm{HNO}_{3}$, and stored chilled until analysis. Samples for isotopic analyses were transferred from the syringe to glass vials without additional filtering and immediately sealed.

Dissolved Ba was determined by inductively coupled plasma-optical emission spectroscopy (ICP-OES) using a Leeman Labs model PS1 echelle grating spectrometer (e.g., De Carlo, 1992) or by mass spectrometry (ICP-MS) using a VG Plasma Quad II-S instrument. The ICP-OES was calibrated using a series of standards prepared by addition of singleelement standards $\left(\mathrm{Ba}^{2+}\right)$ to a $\mathrm{NaCl}$ matrix, as described by De Carlo and Kramer (2000). The ICP-MS was calibrated using a series of aqueous 
E.H. De Carlo et al.

standards diluted from a NIST-traceable stock multielement standard. Instrument drift was monitored at masses 115, 147, and 209 using In, $\mathrm{Sm}$, and $\mathrm{Bi}$ as internal standards.

Dissolved $\mathrm{Rb}^{+}$was determined by atomic emission spectrometry (AES) using the method of standard addition on a Perkin Elmer Model 603 double-beam spectrometer. The atomic emission of $\mathrm{Rb}$ was measured at $780 \mathrm{~nm}$ using a $0.2-\mathrm{nm}$ slit width. Because IW can show wide variations in matrix composition (e.g., salt concentrations), a background correction technique developed in our laboratory for analysis of geothermal and hydrothermal fluids was used (Fraley and De Carlo, unpubl. data). This method compensates for the large background absorption signals often encountered in high-salinity fluids (e.g., De Carlo and Kramer, 2000). A subgroup of IW samples was analyzed for Rb by AES and by ICP-MS to evaluate the comparability of results obtained by the two methods. The methods generally yielded comparable results, although the ICP-MS data seem biased toward lower values than the results obtained by AES.

The oxygen isotopic composition of the pore water samples was determined in the Isotope Biogeochemical Laboratory at the University of Hawaii using a microscale adaptation of Epstein and Mayeda's (1953) $\mathrm{CO}_{2}-\mathrm{H}_{2} \mathrm{O}$ equilibration method, described by Tüchsen et al. (1987). Aliquots of water (120 mg, measured gravimetrically) were equilibrated with $22 \mu \mathrm{mol}$ of $\mathrm{CO}_{2}$ (measured using a calibrated Baratron gauge) at $22^{\circ} \mathrm{C}$ for at least $48 \mathrm{hr}$. The oxygen isotopic composition of purified $\mathrm{CO}_{2}$ was measured using a Finnigan MAT 252 isotope-ratio mass spectrometer. Oxygen isotopic data are expressed in per mil (\%o) deviation from the VSMOW (Vienna standard mean ocean water) standard:

$$
\delta^{18} \mathrm{O}=\left\{\left[\left({ }^{18} \mathrm{O} /{ }^{16} \mathrm{O}\right)_{\text {smpl }} /\left({ }^{18} \mathrm{O} /{ }^{16} \mathrm{O}\right)_{\mathrm{VsMOW}}\right]-1\right\} \times 100 .
$$

The $\delta^{18} \mathrm{O}$ values are normalized such that the $\delta^{18} \mathrm{O}$ value of standard light Antarctic precipitation is $-55.5 \%$. The $2-\sigma$ precision for replicate $\delta^{18} \mathrm{O}$ analyses of samples and the VSMOW standard is $\pm 0.2 \%$.

The isotopic composition of dissolved strontium in the pore water samples was determined at the University of Hawaii Radiogenic Isotope Laboratory. The method used for analyzing strontium isotopic samples in this laboratory was described by Mahoney et al. (1991). The following modifications were applied in the current study: aliquots of pore water samples $(350 \mu \mathrm{L})$ were mixed with equal volumes of $2-\mathrm{N} \mathrm{HCl}$ and loaded onto a $0.6 \mathrm{~cm} \times 20 \mathrm{~cm}$ column of AG50WX8 cation-exchange resin, strontium was eluted with $2-\mathrm{N} \mathrm{HCl}$, each $\mathrm{Sr}$ sample $(150 \mathrm{ng}$ ) was then loaded onto a tungsten filament with a $\mathrm{Ta}_{2} \mathrm{O}_{5}$ substrate, and strontium samples were analyzed in dynamic multicollector mode on a VG sector thermal-ionization mass spectrometer. During the course of analyzing the ODP Leg $180 \mathrm{Sr}$ isotope samples, National Bureau of Standards Standard Reference Material (SRM) 987 was analyzed 11 times, with an average ${ }^{87} \mathrm{Sr} /{ }^{86} \mathrm{Sr}=0.710253$ and a total range of \pm 0.000022 .

A subset of squeeze cakes from Site 1109 was selected for chemical and mineralogical analyses on the basis of the presence of volcanic matter in the sediments (Taylor, Huchon, Klaus, et al., 1999). The clay fraction was separated from the selected squeeze cakes by a combination of wet sieving and gravimetric methods as follows: samples were weighed after freeze drying and divided into a fine $(<63 \mu \mathrm{m})$ and a coarse $(>63$ $\mu \mathrm{m})$ fraction by wet sieving. Subsequent grain-size separation into a silt $(2-63 \mu \mathrm{m})$ and a clay $(<2 \mu \mathrm{m})$ fraction was performed by settling of par- 
ticles in standing cylinders according to Stokes' law (Moore and Reynolds, 1989).

The clay mineralogy was determined by X-ray diffractometry (XRD), using a Philips model PW 1710 X-ray diffractometer equipped with monochromatic $\mathrm{CuK}_{\alpha}$ radiation. Oriented samples were produced by vacuum filtration through a $0.15-\mu \mathrm{m}$ filter. Measurements were carried out on air-dried and glycol-saturated samples. Randomly oriented powder preparations were produced (measurement made over $60-75^{\circ} 2 \theta$ ) to identify di- or trioctahedral clay minerals from $\mathrm{hkl}=060$ reflections.

The clays were dissolved using a CEM model MDS100 microwave digestion system. Approximately $100 \mathrm{mg}$ of each sample was placed in a Teflon reaction vessel, to which were added $500 \mu \mathrm{L}$ of $18 \Omega \mathrm{W}$-cm distilled deionized water, $6 \mathrm{~mL}$ of concentrated $\mathrm{HF}$, and $4 \mathrm{~mL}$ of a 3:1 mixture of concentrated $\mathrm{HNO}_{3}: \mathrm{HCl}$. Samples were sealed, placed in the microwave oven, and digested until no visible residue remained. The vessels were allowed to cool, vented, and the solution evaporated to near dryness. The final paste was redissolved in $0.3-\mathrm{M} \mathrm{HNO}_{3}$, diluted to $\sim 100 \mathrm{~g}$, and weighed to the nearest milligram. Quality control samples included approximately one blank and one SRM (NRC-Canada marine estuarine sediment: MESS-1) for every 10 samples and were carried through all procedures. Trace element concentrations in the digested clay samples were determined by ICP-MS after calibration with a series of multielement standards prepared from serial dilution of a NIST-traceable stock standard. Accuracy of our analyses was verified by comparison of our results for digestions of MESS-1 with other published values (e.g., Garbe-Schönberg, 1993).

\section{RESULTS}

\section{Interstitial Water}

Concentrations of dissolved $\mathrm{Rb}$ and $\mathrm{Ba}$ in IW from Sites 1109, 1115, and 1118 are presented in Table $\mathbf{T} 1$; isotopic compositions $\left(\delta^{18} \mathrm{O}\right.$ and ${ }^{87} \mathrm{Sr} /{ }^{86} \mathrm{Sr}$ ) are given in Table $\mathrm{T} 2$.

Substantial fluctuations in the concentrations of dissolved Ba (Fig. F1) occur downhole. Full depletion of $\mathrm{SO}_{4}^{2-}$ occurs between 100 and 200 mbsf at each site, although $\mathrm{SO}_{4}{ }^{2-}$ reappears in IW deep within Site 1118 (Taylor, Huchon, Klaus, et al., 1999). The absence of $\mathrm{SO}_{4}^{2-}$ throughout a large part of the sedimentary column of each site allows dissolved $\mathrm{Ba}^{2+}$ to accumulate in the IW; yet, the shapes of the depth profiles as well as the range of $\mathrm{Ba}^{2+}$ concentrations vary between sites. Dissolved $\mathrm{Ba}^{2+}$ increases from $<1 \mu \mathrm{M}$ in the upper $50 \mathrm{mbsf}$ (Site 1109) to 100 mbsf (Site 1115), to a maximum of $17.7 \mu \mathrm{M}$ at $480 \mathrm{mbsf}$ at Site 1109. Lesser fluctuations are observed at Sites 1115 and 1118, the latter displaying only about half the $\mathrm{Ba}^{2+}$ concentration range observed at Site 1109.

Dissolved $\mathrm{Rb}^{+}$concentrations also vary widely throughout the sedimentary column of each site (Fig. F1). Concentrations reach two- to threefold enrichment over seawater in localized maxima within Pliocene sediments of Sites 1109 and 1115, although concentrations decrease sharply near the Miocene unconformity. Unlike what was observed for $\mathrm{Ba}^{2+}$, the highest dissolved concentrations of $\mathrm{Rb}^{+}$are present in IW from Site 1118, whereas variations in this constituent are most subdued at Site 1115 , where $\mathrm{Rb}^{+}$remains in a narrow range of $\sim 2-2.5$
T1. Trace element composition of interstitial water, p. 14.

T2. Isotopic composition of interstitial water, p. 17.

F1. Depth profiles of dissolved trace constituents, p. 8.

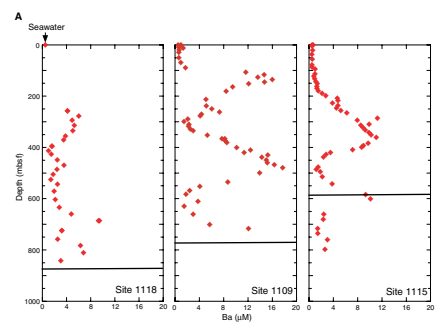


$\mu \mathrm{M}$ in the upper 400 mbsf. Dissolved $\mathrm{Rb}^{+}$is strongly depleted relative to seawater at and below the Miocene unconformity of Sites 1115 and 1109. A near total removal of $\mathrm{Rb}^{+}$from IW occurs near the bottom of Site 1109 , whereas concentrations of $\mathrm{Rb}^{+}$remain more than twice that of bottom seawater in the deepest ( $842 \mathrm{mbsf})$ IW sample collected from Site 1118.

Sr isotope ratios display large variations in IW from the Woodlark Rise sites (Fig. F2). A systematic and similar decrease in ${ }^{87} \mathrm{Sr} /{ }^{86} \mathrm{Sr}$ with increasing depth is observed in the upper $300 \mathrm{mbsf}$ of all three sites. Below this depth, however, values diverge. The widest range in ${ }^{87} \mathrm{Sr} /{ }^{86} \mathrm{Sr}$ ratio in the IW is observed at Site 1115, where it decreases from nearseawater values (e.g., ${ }^{87} \mathrm{Sr} /{ }^{86} \mathrm{Sr}=0.70916$ ) just below the mudline to a minimum of 0.70714 at $601 \mathrm{mbsf}$. The ${ }^{87} \mathrm{Sr} /{ }^{86} \mathrm{Sr}$ ratio increases slightly below 600 mbsf at Site 1115, before settling down near 0.708 in the deepest sections of the hole. IW from Site 1109 displays the narrowest range of ${ }^{87} \mathrm{Sr} /{ }^{86} \mathrm{Sr}$ values of the three Woodlark Rise sites, as well as a profile that mirrors that of Site 1115 between 550 and 750 mbsf. In the deepest portion of Site 1109 the ${ }^{87} \mathrm{Sr} /{ }^{86} \mathrm{Sr}$ ratio decreases sharply again, approaching a value comparable to that observed at the same depth deep in Site 1118.

Profiles of oxygen isotopes in IW from the Woodlark Rise (Fig. F3) exhibit a general decrease in $\delta^{18} \mathrm{O}$ downhole at Sites 1109 and 1115 and in the upper half of Site 1118 (i.e., 258-544 mbsf). At Sites 1109 and 1115 a small increase in the $\delta^{18} \mathrm{O}$ is also observed between 20 and 50 mbsf. Unfortunately, because the upper $200 \mathrm{mbsf}$ of the Site 1118 was drilled but not cored, no data are available for this depth range. At Site 1115, the largest decrease in $\delta^{18} \mathrm{O}$ occurs across the Miocene unconformity, below which a minimum of $-2.84 \%$ is observed at $667 \mathrm{mbsf}$. The trend in $\delta^{18} \mathrm{O}$ values at Site 1109 is similar, although a much more subdued range is observed. The lowest value of $-1.27 \%$ is present in the deepest sample (746 mbsf), which was recovered just above the Miocene unconformity. At Site 1118, there is a relatively steep negative gradient in $\delta^{18} \mathrm{O}$ down to 544 mbsf where a value of $-1.63 \%$ is recorded. However, unlike observed at the two other Woodlark Rise sites, a reversal in the $\delta^{18} \mathrm{O}$ profiles occurs below 571 mbsf at Site 1118 and values trend back toward the contemporaneous seawater value, reaching $-0.86 \%$ at 758 mbsf. Below 758 mbsf and approaching the Miocene unconformity, the profile resumes the decreasing trend in $\delta^{18} \mathrm{O}$, as observed deep in the other Woodlark Rise sites. Overall, the range of $\delta^{18} \mathrm{O}$ values at Site 1109 is small with the lowest value of $-1.27 \%$ measured in the deepest sample (746 mbsf), which was recovered just above the Miocene unconformity.

\section{Mineralogy and Trace Element Composition of Clays}

The trace element composition of the clay fraction $(<2 \mu \mathrm{m})$ of selected whole-round cores corresponding to the IW samples is shown in Table T3. The corresponding X-ray mineralogy is given in Table T4.

The trace element concentrations of the clay samples were normalized to the primitive mantle composition (Hofman, 1988) to help determined their provenance and elucidate the relationship of clays to the abundant volcanic matter dispersed throughout the sediments of Site 1109. The normalized data plotted as "spider diagrams" are shown in Figure F4. The clays generally exhibit similar patterns, with depletion of $\mathrm{Nb}$ and enrichment of $\mathrm{Pb}, \mathrm{Ti}$, and $\mathrm{Hf}$ noted for all samples. The slope of
F2. Depth profiles of the dissolved ${ }^{87} \mathrm{Sr} /{ }^{86} \mathrm{Sr}$ in interstitial water, p. 10.

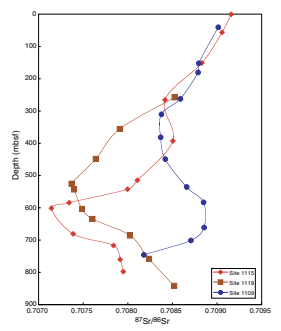

F3. Depth profiles of $\delta^{18} \mathrm{O}$ of interstitial water, p. 11.

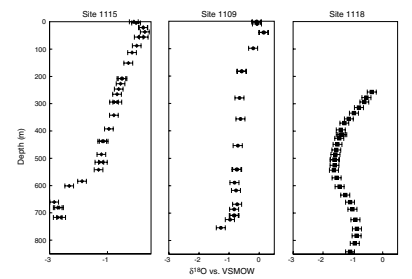

T3. Trace element composition of clays, p. 19.

T4. Mineralogical assemblages of clay fraction, p. 19.

F4. Spider diagrams of trace elements in clay, p. 12.

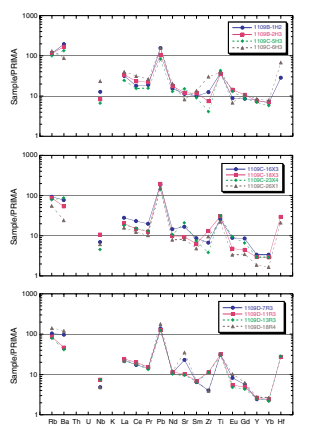


E.H. De CARLo et AL.

the patterns is steepest in the samples collected deep within Site 1109, except from Section 180-1109D-38R-4, whereas samples recovered from younger sediments display less fractionated patterns. The level of enrichment or depletion relative to the trend described by the other trace elements, however, is subject to substantial variability. Additionally, selected clays display enrichments in $\mathrm{Sr}$ and $\mathrm{Zr}$ (and to a lesser extent Gd). Some samples recovered deeper within the sedimentary column, especially between Section 180-1109C-39X-2 and Section 39R-2 show a greater $\mathrm{Sr}$ enrichment relative to other samples. In the case of $\mathrm{Zr}$, however, the enrichment is more variable, with no uniform pattern observed with increasing depth downhole. In fact, some samples recovered from younger sediments display the highest $\mathrm{Zr}$ enrichment (e.g., Section 180-1109D-6H-3). Clay isolated from the conglomerate interval (Section 180-1109D-34R-4) exhibits the lowest trace element enrichment as well as less fractionation across the trace element series than clays isolated from younger sediments. The clay sample recovered from below the Miocene unconformity (e.g., Section 180-1109D-38R-4) exhibits little fractionation across the series of elements comprising the spider diagram, including lower normalized $\mathrm{Rb}$ and $\mathrm{Ba}$ abundances than most other clays, although it does not have the lowest overall trace element concentrations. The latter is particularly true toward the end of the trace element series (e.g., Ti, Eu, Gd, Y, and $\mathrm{Yb}$ ), where this sample actually exhibits the highest enrichment of these elements.

XRD investigations were conducted to identify the mineral assemblages of the clay fraction and to determine the composition and distribution of the various minerals. Quartz, feldspar, and illite are considered of detrital origin in all holes, representing the background hemipelagic sedimentary supply (Taylor, Huchon, Klaus, et al. 1999). The presence of talc and serpentine minerals in Sections 180-1109C10H-4 to 26X-1 indicates erosion of metamorphic rocks for which the D'Entrecasteaux Islands or Papuan Peninsula are the obvious source areas. The XRD data indicate the presence of a significant amount of mixed-layer chlorite/smectite clays, suggesting a distinctive provenance for these intervals. The increased abundance of smectite with increasing depth downhole is probably related to an increase of volcanic alteration supported by advanced devitrification of volcanic glass shards.

\section{ACKNOWLEDGMENTS}

This research used samples and/or data provided by the Ocean Drilling Program (ODP). ODP is sponsored by the U.S. National Science Foundation (NSF) and participating countries under management of Joint Oceanographic Institutions (JOI), Inc. Funding for this research was provided by a postcruise research grant to EDC from JOI/USSP. This is SOEST contribution No. 5572.

We wish to acknowledge the Captain and crew of the JOIDES Resolution and the ODP technical staff for a very successful cruise. We are particularly indebted to shipboard chemistry technicians Chieh Peng and Dennis Graham for their able assistance. C.M. Fraley and P. Carlton provided technical assistance at SOEST. P. Anschutz provided a review of this report. 


\section{REFERENCES}

De Carlo, E.H., 1992. Geochemistry of pore water and sediments recovered from the Exmouth Plateau. In von Rad, U., Haq, B.U., et al., Proc. ODP, Sci. Results, 122: College Station, TX (Ocean Drilling Program), 295-308.

De Carlo, E.H., and Kramer, P.A., 2000. Minor and trace elements in interstitial waters of the Great Bahama Bank: results from ODP Leg 166. In Swart, P.K., Eberli, G.P., Malone, M.J., and Sarg, J.F. (Eds.), Proc. ODP, Sci. Results, 166: College Station TX (Ocean Drilling Program), 99-111.

Epstein, S., and Mayeda, T., 1953. Variation of ${ }^{18} \mathrm{O}$ content of waters from natural sources. Geochim. Cosmochim. Acta, 4:213-224.

Garbe-Schönberg, C.D., 1993. Simultaneous determination of 37 trace elements in 28 international rock standards by ICP/MS. Geostand. Newsl., 17:81-97.

Hofman, A.W., 1988. Chemical differentiation of the Earth: the relationship between mantle, continental crust and oceanic crust. Earth Planet. Sci. Lett., 90:297-314.

Mahoney, J., Nicollet, C., and Dupuy, C., 1991. Madagascar basalts: tracking oceanic and continental sources. Earth Planet. Sci. Lett., 104:350-363.

Manheim, F.T., and Sayles, F.L., 1974. Composition and origin of interstitial waters of marine sediments, based on deep sea drill cores. In Goldberg, E.D. (Ed.), The Sea (Vol. 5): Marine Chemistry: The Sedimentary Cycle: New York (Wiley), 527-568.

Moore, D.M., and Reynolds, R.C., Jr., 1989. X-ray Diffraction and the Identification and Analysis of Clay Minerals: Oxford (Oxford Univ. Press).

Taylor, B., Huchon, P., Klaus, A., et al., 1999. Proc. ODP, Init. Repts., 180 [CD-ROM]. Available from: Ocean Drilling Program, Texas A\&M University, College Station, TX 77845-9547, U.S.A.

Tüchsen, E., Hayes, J.M., Ramaprasad, S., Copie, V., and Woodward, C., 1987. Solvent exchange of buried water and hydrogen exchange of peptide $\mathrm{NH}$ groups hydrogen bonded to buried water in bovine pancreatic trypsin inhibitor. Biochemistry, 26:5163-5172. 
Figure F1. Depth profiles of dissolved trace constituents (A) Ba and (B) Rb in interstitial water from Sites 1109, 1115 and 1118 on the Woodlark Rise. The concentration of each constituent in seawater is indicated by an arrow at the top of the Site 1118 depth profile. The sedimentary unconformity at each site is shown by a solid line drawn across each profile at the appropriate depth. (Continued on next page.)

A
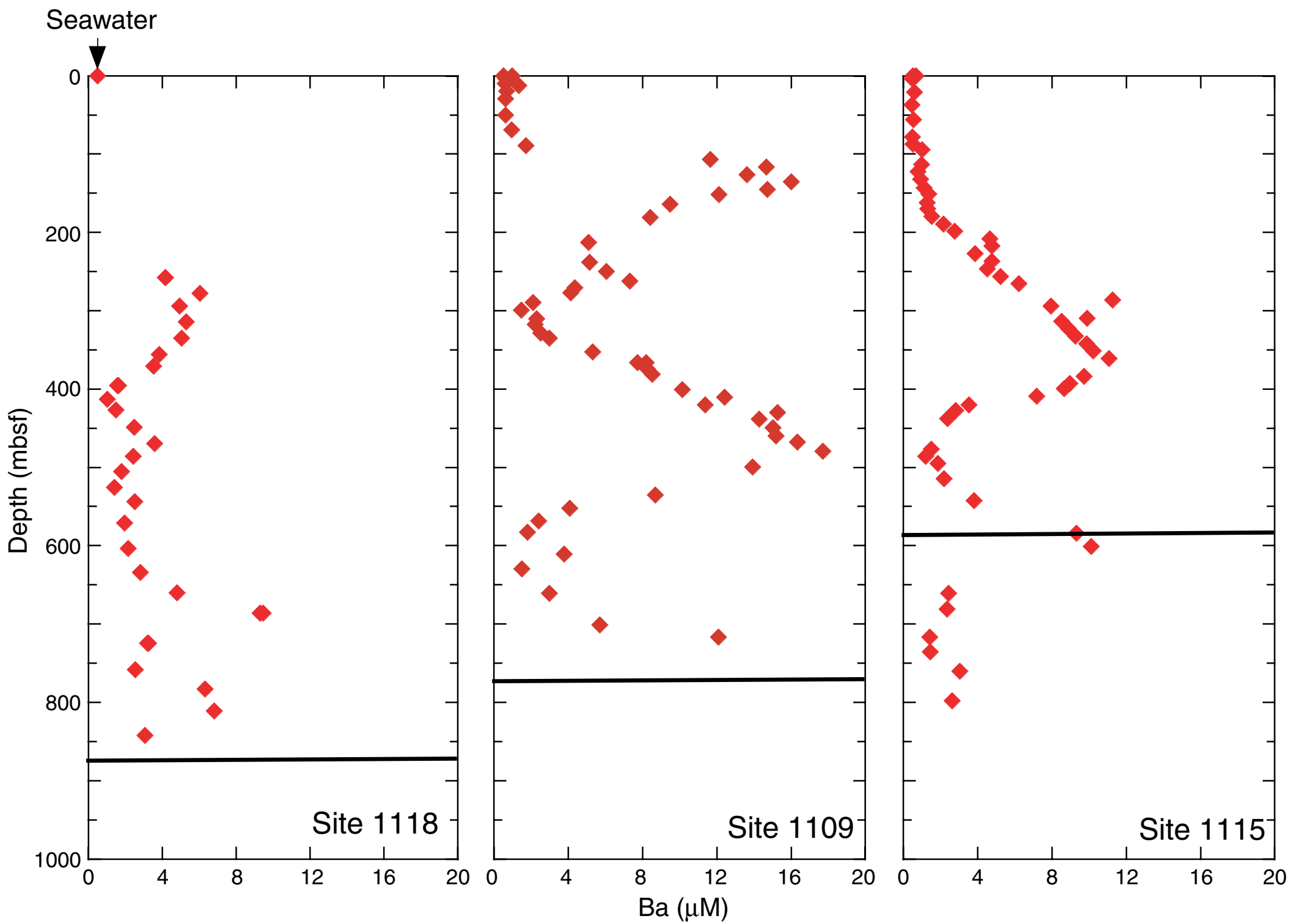
Figure F1 (continued). (Caption shown on previous page.)

B
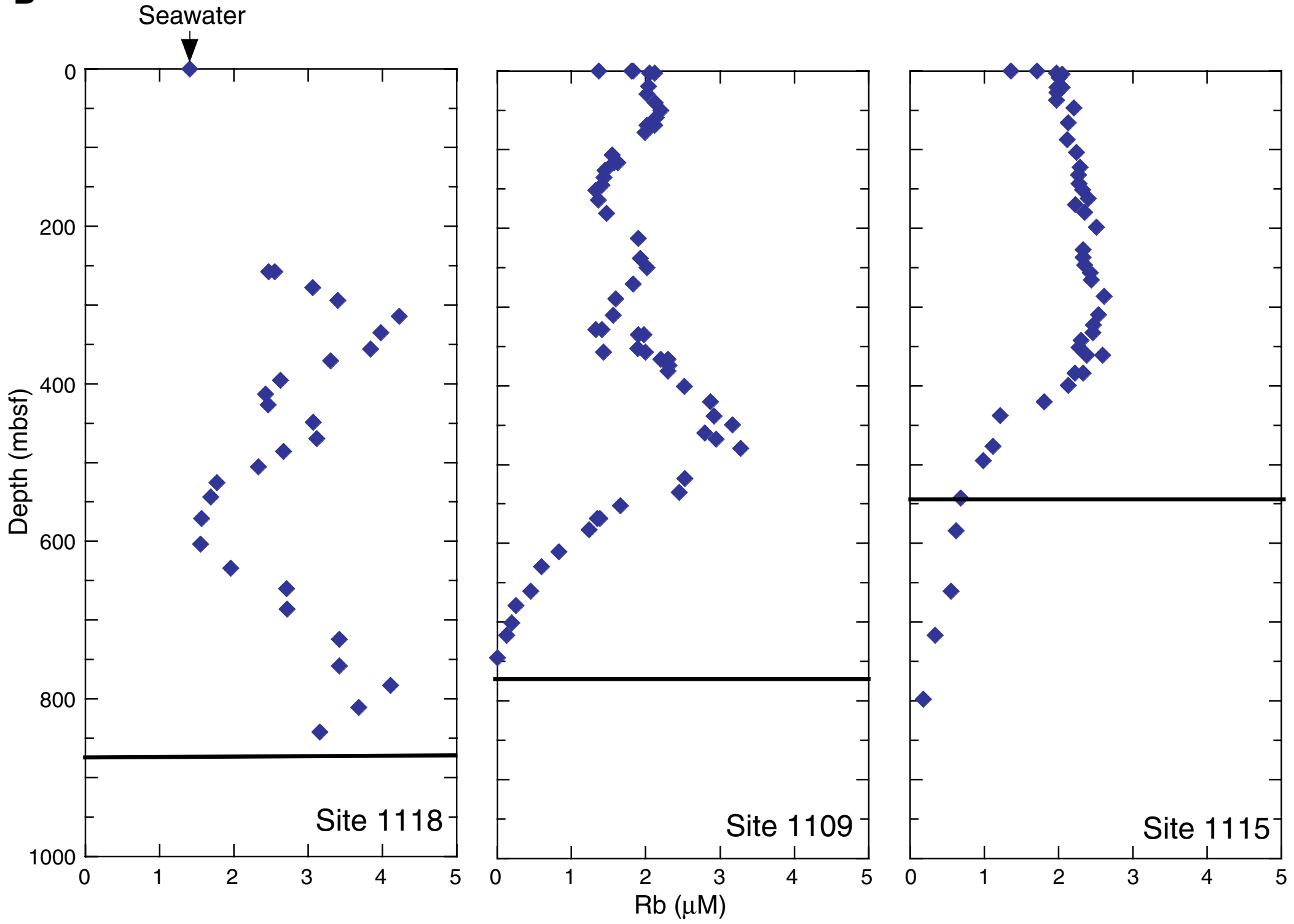

要 
E.H. De CARlo et al.

DATA REPORT: COMPOSITION OF INTERSTITIAL WATER

Figure F2. Depth profiles of the dissolved ${ }^{87} \mathrm{Sr} /{ }^{86} \mathrm{Sr}$ in interstitial water from Sites 1109,1115 , and 1118 on the Woodlark Rise. Solid circles $=$ Site 1109, solid diamonds $=$ Site 1115, solid squares $=$ Site 1118 .

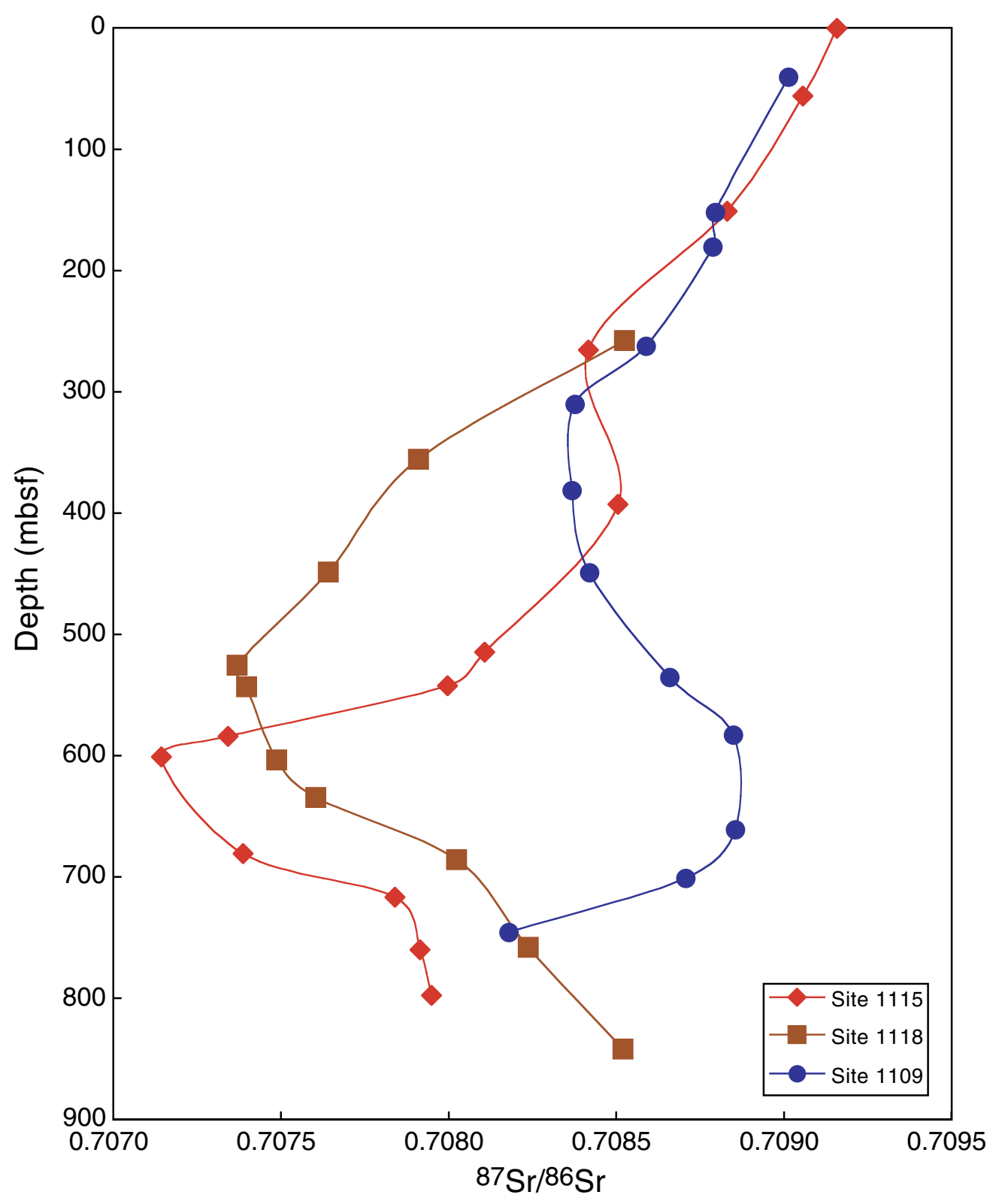


Figure F3. Depth profiles of $\delta^{18} \mathrm{O}$ of interstitial water from Sites 1115, 1109, and 1118 on the Woodlark Rise. Error bars represent the instrumental precision for each measurement. VSMOW = Vienna standard mean ocean water.
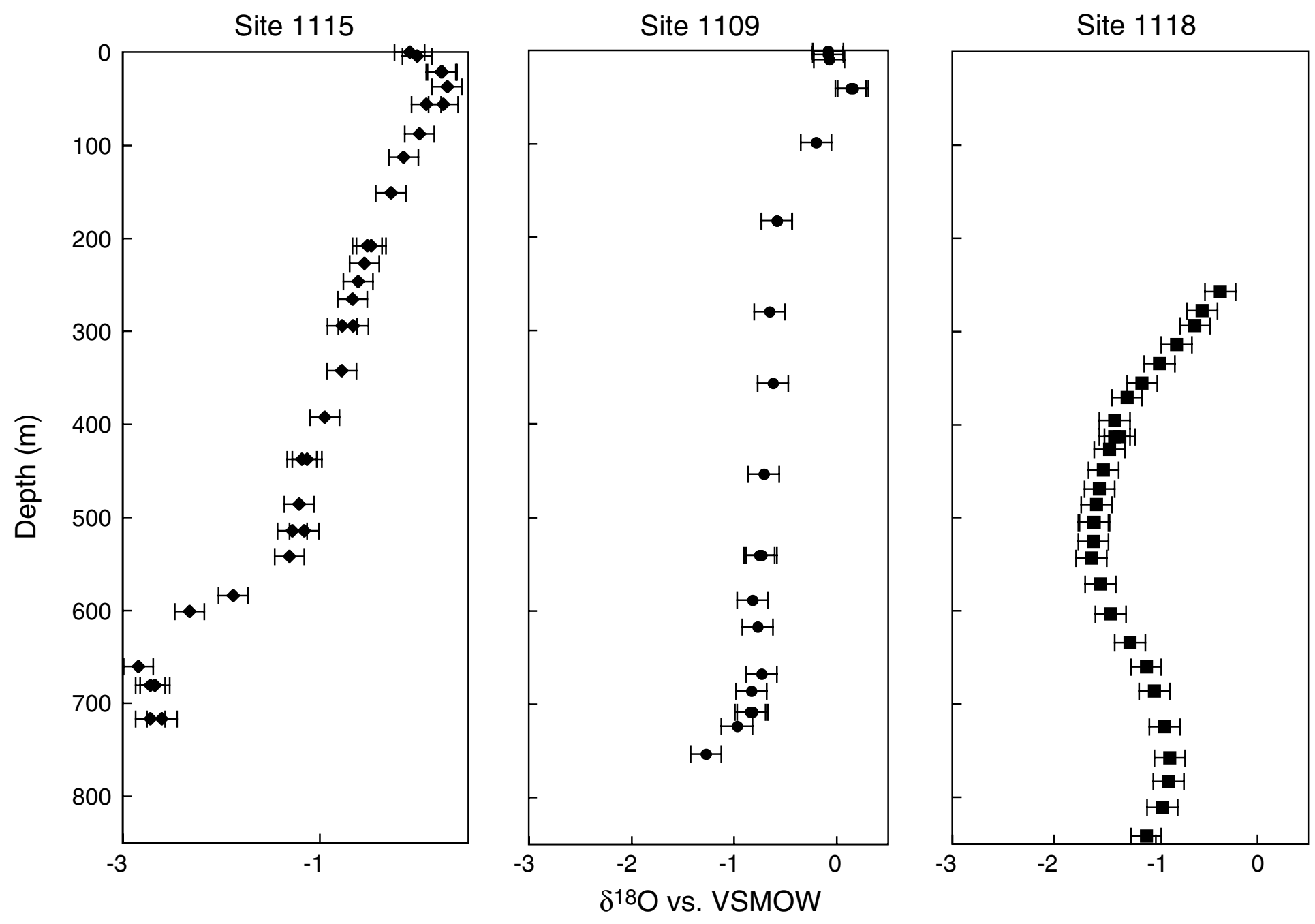
E.H. De Carlo et al.

DATA REPORT: Composition OF INTERSTITIAL WATER

Figure F4. Spider diagrams of trace elements in clays from Site 1109. All concentrations have been normalized to the primitive mantle (PRIMA) (Hoffman, 1988). (Continued on next page.)
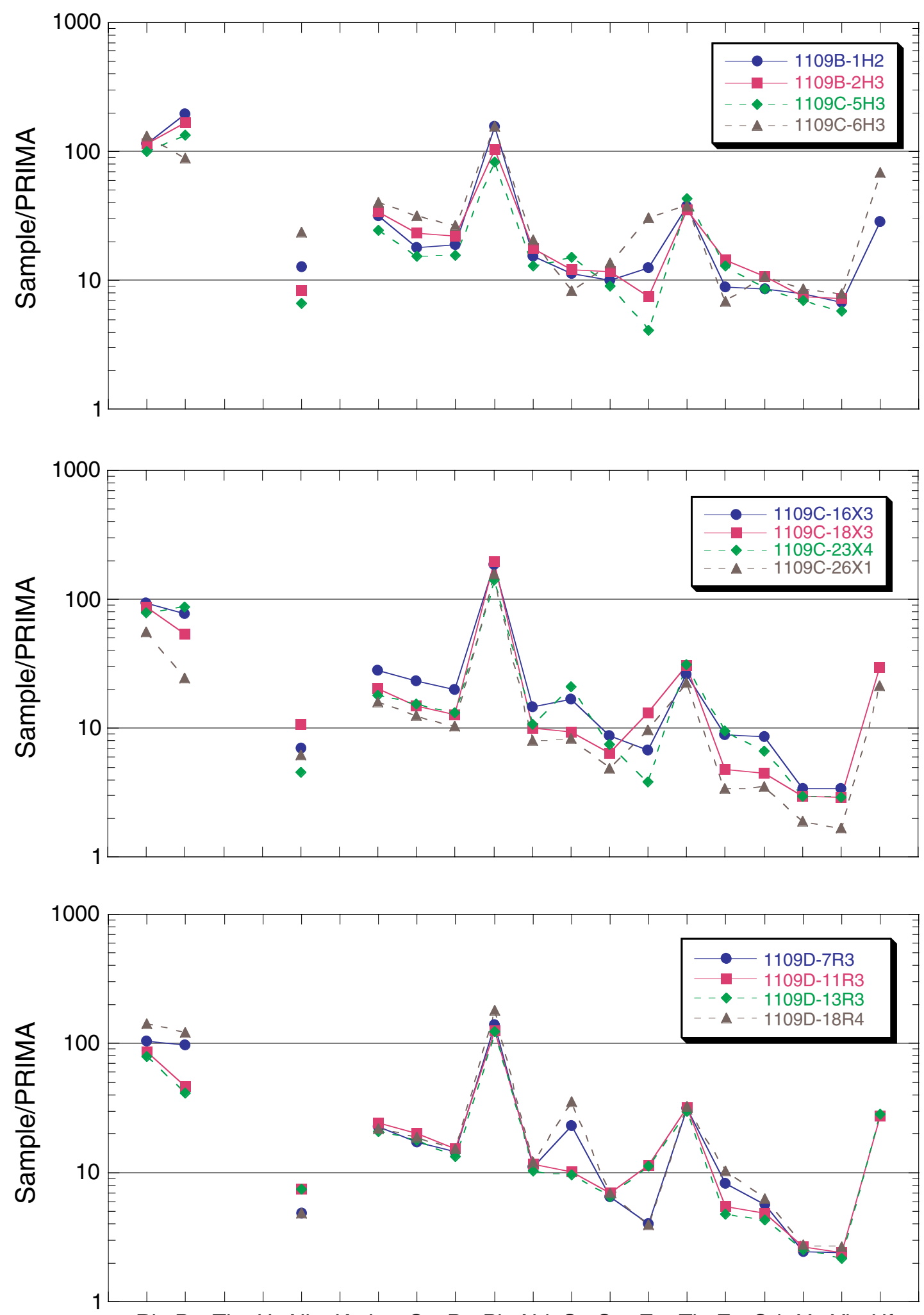

$\mathrm{Rb} \mathrm{Ba} \mathrm{Th} U \mathrm{Nb} K \mathrm{Ka} \mathrm{Ce} \mathrm{Pr} \mathrm{Pb} \mathrm{Nd} \mathrm{Sr} \mathrm{Sm} \mathrm{Zr} \mathrm{Ti}$ Eu Gd Y Yb Hf 
E.H. DE CARLo et al.

DATA REPORT: COMPOSITION OF INTERSTITIAL WATER

Figure F4 (continued). (Caption shown on previous page.)
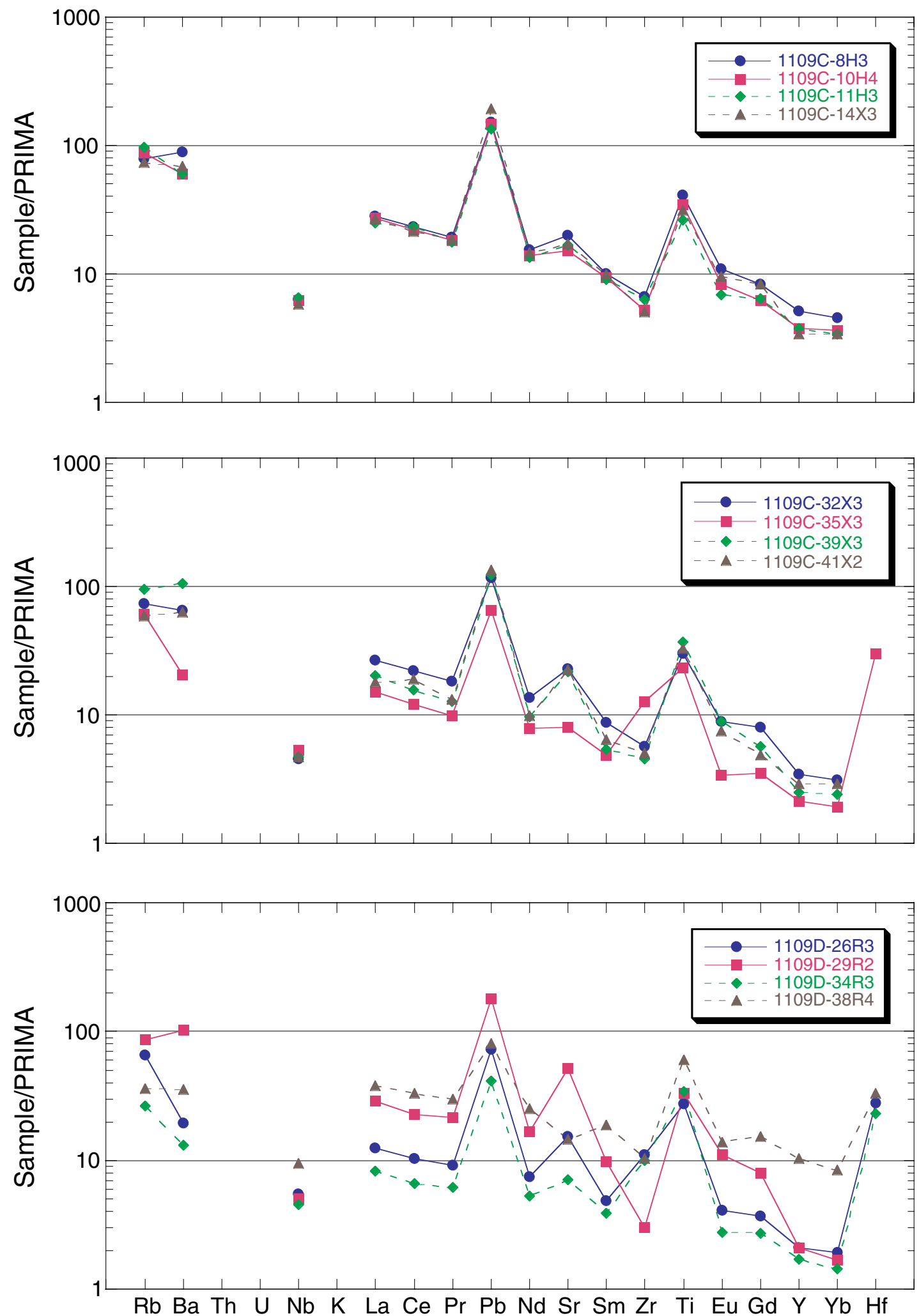
E.H. De CARLo et AL.

DATA REPORT: CoMposition OF INTERSTITIAL WATER

Table T1. Trace element composition of interstitial water, Sites 1109, 1115, and 1118. (See table note. Continued on next two pages.)

\begin{tabular}{|c|c|c|c|c|c|}
\hline \multirow{2}{*}{$\begin{array}{l}\text { Core, section, } \\
\text { interval }(\mathrm{cm})\end{array}$} & \multirow{2}{*}{$\begin{array}{l}\text { Depth } \\
\text { (mbsf) }\end{array}$} & \multicolumn{2}{|c|}{$\mathrm{Ba}(\mu \mathrm{M})$} & \multicolumn{2}{|c|}{$\mathrm{Ba}(\mu \mathrm{M})$} \\
\hline & & AES & ICP-MS & ICP-OES & ICP-MS \\
\hline \multicolumn{6}{|l|}{ 180-1109B- } \\
\hline $1 \mathrm{H}-1,35-40$ & 0.4 & 1.82 & & 1.0 & \\
\hline $1 \mathrm{H}-2,145-150$ & 2.9 & 2.09 & & & \\
\hline $1 \mathrm{H}-3,145-150$ & 4.4 & & & 0.7 & \\
\hline $2 \mathrm{H}-1,145-150$ & 6.8 & & & & \\
\hline $2 \mathrm{H}-3,145-150$ & 9.8 & & & 0.6 & \\
\hline $2 \mathrm{H}-4,75-80$ & 10.6 & & & & \\
\hline $2 \mathrm{H}-5,145-150$ & 12.1 & & & 1.3 & \\
\hline $2 \mathrm{H}-6,145-150$ & 13.6 & & & & \\
\hline \multicolumn{6}{|l|}{ 180-1109C- } \\
\hline $3 \mathrm{H}-2,145-150$ & 19.9 & 2.04 & & 0.7 & \\
\hline $4 \mathrm{H}-2,145-150$ & 29.4 & 2.02 & & 0.6 & \\
\hline $5 \mathrm{H}-3,145-150$ & 40.4 & 2.13 & & & \\
\hline $6 \mathrm{H}-3,145-150$ & 49.9 & 2.20 & & 0.6 & \\
\hline $7 \mathrm{H}-3,145-150$ & 59.4 & 2.14 & & & \\
\hline $8 \mathrm{H}-3,145-150$ & 68.9 & 2.12 & & 0.9 & \\
\hline $8 \mathrm{H}-3,145-120$ & 68.9 & 2.02 & & & \\
\hline $9 \mathrm{H}-3,145-150$ & 78.4 & 1.99 & & & \\
\hline $10 \mathrm{H}-4,115-120$ & 89.1 & & & 1.7 & \\
\hline $12 X-3,145-150$ & 106.9 & 1.55 & & 11.7 & \\
\hline $13 X-3,145-150$ & 116.5 & 1.60 & & 14.7 & \\
\hline $14 \mathrm{X}-3,145-150$ & 126.1 & 1.44 & & 13.6 & \\
\hline $15 X-3,145-150$ & 135.6 & 1.44 & & 16.0 & \\
\hline $16 X-3,145-150$ & 145.3 & 1.41 & & 14.7 & \\
\hline $17 X-1,145-150$ & 152 & 1.33 & & 12.1 & \\
\hline $18 X-3,115-120$ & 164.3 & 1.36 & & 9.5 & \\
\hline $20 X-1,140-150$ & 180.7 & 1.47 & & 8.4 & \\
\hline $23 X-4,33-43$ & 212.4 & 1.90 & & 5.1 & \\
\hline $26 \mathrm{X}-1,140-145$ & 238.4 & 1.93 & & 5.2 & \\
\hline $27 X-2,140-150$ & 249.6 & 2.02 & & 6.1 & \\
\hline $28 X-4,140-150$ & 262.2 & & & 7.3 & \\
\hline $29 \mathrm{X}-3,140-150$ & 270.4 & 1.83 & & 4.4 & \\
\hline $30 X-1,140-150$ & 277 & & & 4.1 & \\
\hline $31 X-3,140-150$ & 289.5 & 1.60 & & 2.1 & \\
\hline $32 X-3,140-150$ & 299.2 & & & 1.5 & \\
\hline $33 X-4,115-120$ & 310.2 & 1.56 & & 2.3 & \\
\hline $34 \mathrm{X}-2,140-150$ & 317.1 & & & 2.2 & \\
\hline $35 X-3,140-150$ & 328.3 & 1.37 & & 2.5 & \\
\hline $36 X-1,140-150$ & 334.9 & 1.94 & & 3.0 & \\
\hline $38 X-4,140-150$ & 352.5 & 1.89 & & 5.3 & \\
\hline $39 X-3,140-150$ & 357 & 1.43 & & & \\
\hline $40 X-3,110-120$ & 366.3 & 2.20 & & 7.7 & \\
\hline $41 X-2,140-150$ & 374.4 & 2.31 & & 8.3 & \\
\hline \multicolumn{6}{|l|}{ 180-1109D- } \\
\hline 2R-6, 96-106 & 365.9 & 2.30 & & 8.2 & \\
\hline $4 R-3,96-106$ & 381.6 & 2.30 & & 8.5 & \\
\hline 6R-3, 97-107 & 401 & 2.52 & & 10.1 & \\
\hline $7 R-3,120-130$ & 410.7 & & & 12.4 & \\
\hline $8 R-3,141-151$ & 420.3 & 2.87 & & 11.4 & \\
\hline 9R-3, 101-111 & 430.1 & & & 15.3 & \\
\hline 10R-2, 131-141 & 438.4 & 2.92 & & 14.3 & \\
\hline $11 \mathrm{R}-3,122-132$ & 449.3 & 3.17 & & 15.0 & \\
\hline $12 \mathrm{R}-4,120-130$ & 460.1 & 2.80 & & 15.2 & \\
\hline $13 \mathrm{R}-3,79-89$ & 467.9 & 2.95 & & 16.3 & \\
\hline $14 R-4,136-146$ & 479.3 & 3.28 & & 17.7 & \\
\hline 16R-5, & 499.7 & & & 13.9 & \\
\hline $18 \mathrm{R}-4,120-130$ & 517.7 & 2.53 & & & \\
\hline $20 \mathrm{R}-3,65-75$ & 535.4 & 2.45 & & 8.7 & \\
\hline $22 \mathrm{R}-1,124-134$ & 552.4 & 1.66 & & 4.1 & \\
\hline 24R-2, 135-148 & 568.4 & 1.38 & & 2.4 & \\
\hline 24R-2, 135-148 & 568.4 & 1.35 & & & \\
\hline $26 \mathrm{R}-3,30-40$ & 583 & 1.24 & & 1.8 & \\
\hline 29R-2, 93-103 & 610.9 & 0.83 & & 3.8 & \\
\hline $31 \mathrm{R}-1,130-140$ & 629.5 & 0.60 & & 1.5 & \\
\hline $34 \mathrm{R}-3,123-133$ & 661 & 0.45 & & 3.0 & \\
\hline
\end{tabular}


E.H. De CARLo et AL.

DATA REPORT: COMPOSITION OF INTERSTITIAL WATER

Table T1 (continued).

\begin{tabular}{|c|c|c|c|c|c|}
\hline \multirow{2}{*}{$\begin{array}{l}\text { Core, section, } \\
\text { interval }(\mathrm{cm})\end{array}$} & \multirow{2}{*}{$\begin{array}{l}\text { Depth } \\
\text { (mbsf) }\end{array}$} & \multicolumn{2}{|c|}{$\mathrm{Ba}(\mu \mathrm{M})$} & \multicolumn{2}{|c|}{$\mathrm{Ba}(\mu \mathrm{M})$} \\
\hline & & AES & ICP-MS & ICP-OES & ICP-MS \\
\hline $36 \mathrm{R}-2,140-150$ & 679.3 & 0.25 & & & \\
\hline $38 \mathrm{R}-4,140-150$ & 701.2 & 0.20 & & 5.7 & \\
\hline 40R-2, 29-39 & 716.6 & 0.13 & & 12.1 & \\
\hline $43 R-2,82-89$ & 745.7 & 0.00 & & & \\
\hline \multicolumn{6}{|l|}{ 180-1115A- } \\
\hline $1 \mathrm{H}-1,23-28$ & 0.23 & 1.71 & & 0.7 & \\
\hline $1 \mathrm{H}-3,145-150$ & 2.95 & 1.97 & & & \\
\hline $1 \mathrm{H}-4,115-120$ & 4.15 & 2.05 & & 0.5 & \\
\hline \multicolumn{6}{|l|}{ 180-1115B- } \\
\hline $2 \mathrm{H}-1,145-150$ & 8.65 & 2.01 & & & \\
\hline $3 \mathrm{H}-3,145-150$ & 21.15 & 2.02 & & 0.6 & \\
\hline $4 \mathrm{H}-1,145-150$ & 27.65 & 1.98 & & & \\
\hline $5 \mathrm{H}-1,145-150$ & 37.15 & 1.97 & & 0.5 & \\
\hline $6 \mathrm{H}-1,145-150$ & 46.65 & 2.21 & & & \\
\hline $7 \mathrm{H}-1,145-150$ & 56.15 & & & 0.6 & \\
\hline $8 \mathrm{H}-1,145-150$ & 65.65 & 2.13 & & & \\
\hline $9 \mathrm{H}-3,145-150$ & 78.15 & & & 0.5 & \\
\hline $10 \mathrm{H}-3,145-150$ & 87.65 & 2.12 & & 0.5 & \\
\hline $11 \mathrm{H}-1,145-150$ & 94.15 & & & 1.0 & \\
\hline $12 \mathrm{H}-1,145-150$ & 103.65 & 2.24 & & & \\
\hline $13 \mathrm{H}-1,145-150$ & 113.15 & & & 1.0 & \\
\hline $14 \mathrm{H}-1,145-150$ & 122.65 & 2.29 & & 0.8 & \\
\hline $15 \mathrm{H}-1,145-150$ & 132.15 & 2.27 & & 0.9 & \\
\hline $16 \mathrm{H}-2,145-150$ & 143.15 & 2.28 & & 1.1 & \\
\hline $17 \mathrm{H}-1,145-150$ & 151.15 & 2.32 & & 1.4 & \\
\hline $18 \mathrm{H}-2,145-150$ & 162.15 & 2.40 & & 1.3 & \\
\hline $19 \mathrm{H}-1,145-150$ & 170.15 & 2.23 & & 1.3 & \\
\hline $20 \mathrm{H}-1,145-150$ & 179.65 & 2.35 & & 1.5 & \\
\hline $21 \mathrm{H}-1,145-150$ & 189.15 & & & 2.2 & \\
\hline $22 \mathrm{H}-1,145-150$ & 198.65 & 2.51 & & 2.8 & \\
\hline $23 \mathrm{H}-1,145-150$ & 208.15 & & & 4.7 & \\
\hline $24 X-1,145-150$ & 217.65 & & & 4.8 & \\
\hline $25 X-1,145-150$ & 227.25 & 2.33 & & 3.9 & \\
\hline $26 X-1,115-120$ & 236.55 & 2.33 & & 4.8 & \\
\hline $27 X-1,145-150$ & 246.45 & 2.35 & & 4.5 & \\
\hline $28 X-1,145-150$ & 256.05 & 2.43 & & 5.2 & \\
\hline $29 X-1,145-150$ & 265.75 & 2.44 & & 6.2 & \\
\hline $31 X-2,145-150$ & 286.45 & 2.61 & & 11.3 & \\
\hline \multicolumn{6}{|l|}{ 180-1115C- } \\
\hline 2R-1, 144-150 & 294.24 & & & 7.9 & \\
\hline $3 R-5,115-120$ & 309.65 & 2.54 & & 9.9 & \\
\hline $4 R-1,146-151$ & 313.56 & & & 8.5 & \\
\hline $5 R-1,120-127$ & 322.9 & 2.47 & & 8.9 & \\
\hline $6 R-1,140-145$ & 332.8 & 2.46 & & 9.3 & \\
\hline 7R-1, 141-146 & 342.41 & 2.30 & & 9.9 & \\
\hline $8 R-1,79-84$ & 351.39 & 2.28 & & 10.2 & \\
\hline 9R-1, 113-119 & 361.03 & 2.49 & & 11.1 & \\
\hline $10 R-1,145-150$ & 370.95 & & & & \\
\hline $11 R-4,30-41$ & 383.72 & 2.28 & & 9.7 & \\
\hline $12 \mathrm{R}-3,130-140$ & 392.8 & & & 9.0 & \\
\hline $13 R-2,0-14$ & 399.6 & 2.13 & & 8.7 & \\
\hline $14 \mathrm{R}-1,135-144$ & 409.05 & & & 7.2 & \\
\hline $15 R-2,140-150$ & 420.2 & 1.81 & & 3.5 & \\
\hline 16R-1 69-79 & 427.59 & & & 2.8 & \\
\hline 17R-1, 109-119 & 437.59 & 1.21 & & 2.4 & \\
\hline $21 R-2,86-96$ & 476.58 & 1.12 & & 1.5 & \\
\hline $22 \mathrm{R}-1$ 140-150 & 485.9 & & & 1.2 & \\
\hline $23 \mathrm{R}-1,123-138$ & 495.33 & 0.99 & & 1.9 & \\
\hline $25 \mathrm{R}-1,140-150$ & 514.8 & & & 2.2 & \\
\hline $28 \mathrm{R}-1,20-30$ & 542.4 & 0.68 & & 3.8 & \\
\hline $32 R-3,116-126$ & 584.11 & 0.62 & & 9.3 & \\
\hline $34 \mathrm{R}-1,138-148$ & 601.18 & & & 10.1 & \\
\hline $40 R-2,140-150$ & 660.7 & 0.55 & & 2.5 & \\
\hline $42 \mathrm{R}-3,140-150$ & 680.79 & & & 2.4 & \\
\hline $44 \mathrm{R}-1,98-108$ & 697.48 & & & & \\
\hline $46 \mathrm{R}-1,105-115$ & 716.75 & 0.34 & & 1.4 & \\
\hline $48 \mathrm{R}-1,78-88$ & 735.88 & & & 1.5 & \\
\hline
\end{tabular}


E.H. De CARLo et AL.

DATA REPORT: COMPOSITION OF INTERSTITIAL WATER

Table T1 (continued).

\begin{tabular}{|c|c|c|c|c|c|}
\hline \multirow{2}{*}{$\begin{array}{l}\text { Core, section, } \\
\text { interval }(\mathrm{cm})\end{array}$} & \multirow{2}{*}{$\begin{array}{l}\text { Depth } \\
\text { (mbsf) }\end{array}$} & \multicolumn{2}{|c|}{$\mathrm{Ba}(\mu \mathrm{M})$} & \multicolumn{2}{|c|}{$\mathrm{Ba}(\mu \mathrm{M})$} \\
\hline & & AES & ICP-MS & ICP-OES & ICP-MS \\
\hline 50R-5, 90-102 & 760.13 & & & 3.0 & \\
\hline $52 \mathrm{R}-1,103-113$ & 774.63 & & & & \\
\hline $54 \mathrm{R}-4,140-150$ & 798.14 & 0.18 & & 2.6 & \\
\hline \multicolumn{6}{|l|}{ 180-1118A- } \\
\hline $6 \mathrm{R}-4,140-150$ & 257.8 & 2.51 & 2.12 & & 4.19 \\
\hline $8 R-4,140-150$ & 278 & 3.06 & 2.72 & & 6.07 \\
\hline $10 \mathrm{R}-2,140-150$ & 294.3 & 3.40 & 3.03 & & 4.95 \\
\hline $12 \mathrm{R}-3,111-121$ & 314.3 & 4.23 & 3.63 & & 5.34 \\
\hline $14 \mathrm{R}-4,131-141$ & 335.1 & 3.98 & 3.60 & & 5.01 \\
\hline 16R-5, 91-101 & 355.9 & 3.84 & 3.42 & & 3.83 \\
\hline $18 \mathrm{R}-2,128-137$ & 371 & 3.30 & 3.02 & & 3.58 \\
\hline $20 \mathrm{R}-6,134-146$ & 395.8 & 2.63 & 2.41 & & 1.63 \\
\hline $20 \mathrm{R}-6,134-146$ & 395.8 & 2.40 & 2.40 & & 1.57 \\
\hline $22 \mathrm{R}-5,112-123$ & 413.1 & 2.43 & 2.23 & & 1.05 \\
\hline $24 \mathrm{R}-1,134-146$ & 426.9 & 2.46 & 2.22 & & 1.53 \\
\hline 26R-3, 110-119 & 448.9 & 3.07 & 2.78 & & 2.48 \\
\hline 28R-4, 107-117 & 469.4 & 3.12 & 2.89 & & 3.58 \\
\hline 30R-2, 132-142 & 486 & 2.67 & 2.44 & & 2.44 \\
\hline $32 \mathrm{R}-2,131-141$ & 505.3 & 2.33 & 2.08 & & 1.81 \\
\hline $34 \mathrm{R}-3,116-131$ & 525.7 & 1.77 & 1.63 & & 1.41 \\
\hline $36 \mathrm{R}-2,135-145$ & 543.5 & 1.69 & 1.56 & & 2.46 \\
\hline $39 \mathrm{R}-1,138-150$ & 571.4 & 1.57 & 1.44 & & 2.00 \\
\hline $42 \mathrm{R}-4,98-110$ & 603.6 & 1.55 & 1.40 & & 2.15 \\
\hline $45 R-6,92-102$ & 634.6 & 1.96 & 1.76 & & 2.82 \\
\hline $48 \mathrm{R}-3,112-122$ & 660.4 & 2.71 & 2.44 & & 4.77 \\
\hline $51 \mathrm{R}-1,74-89$ & 686 & & 2.79 & & 9.22 \\
\hline $51 \mathrm{R}-1,74-89$ & 686 & 2.72 & 2.85 & & 9.42 \\
\hline $55 \mathrm{R}-1,72-87$ & 724.8 & 3.42 & 3.42 & & 3.17 \\
\hline $55 \mathrm{R}-1,72-87$ & 724.8 & & 3.57 & & 3.25 \\
\hline $58 \mathrm{R}-4,135-150$ & 758.2 & 3.42 & 3.57 & & 2.49 \\
\hline $61 \mathrm{R}-1,113-128$ & 783 & 4.11 & 4.04 & & 6.24 \\
\hline $64 \mathrm{R}-1,9-21$ & 810.8 & 3.68 & 3.98 & & 6.81 \\
\hline $67 \mathrm{R}-2,135-150$ & 842.2 & 3.13 & 2.52 & & 3.12 \\
\hline
\end{tabular}

Note: $\mathrm{AES}=$ atomic emission spectroscopy, ICP-MS = inductively coupled plasma-mass spectroscopy, ICP-OES = inductively coupled plasma-optical emission spectroscopy. 
E.H. De CARLo et AL.

DATA REPORT: COMPOSITION OF INTERSTITIAL WATER

Table T2. Isotopic composition of interstitial water, Sites 1109, 1115, and 1118. (Continued on next page.)

\begin{tabular}{|c|c|c|c|c|c|c|c|}
\hline $\begin{array}{l}\text { Core, section, } \\
\text { interval }(\mathrm{cm})\end{array}$ & $\begin{array}{l}\text { Depth } \\
\text { (mbsf) }\end{array}$ & ${ }^{87} \mathrm{Sr} /{ }^{86} \mathrm{Sr}$ & $\begin{array}{c}2-\sigma \\
\text { uncertainty }\end{array}$ & $\begin{array}{l}\text { Replicate } \\
{ }^{87} \mathrm{Sr} / 86 \mathrm{Sr}\end{array}$ & $\begin{array}{c}2-\sigma \\
\text { uncertainty }\end{array}$ & $\delta^{18} \mathrm{O}$ & $\begin{array}{c}\text { Replicate } \\
\delta^{18} \mathrm{O}\end{array}$ \\
\hline \multicolumn{8}{|l|}{ 180-1109B- } \\
\hline $1 \mathrm{H}-1,35-40$ & 0.4 & & & & & -0.08 & \\
\hline $1 \mathrm{H}-3,145-150$ & 4.4 & & & & & -0.08 & \\
\hline $2 \mathrm{H}-3,145-150$ & 9.8 & & & & & -0.07 & \\
\hline \multicolumn{8}{|l|}{ 180-1109C- } \\
\hline $5 \mathrm{H}-3,145-150$ & 40.4 & 0.709014 & 0.000016 & & & 0.16 & 0.14 \\
\hline $11 \mathrm{H}-3,145-150$ & 97.4 & & & & & -0.2 & \\
\hline $17 X-1,145-150$ & 152.0 & 0.708796 & 0.000013 & & & & \\
\hline $20 X-1,140-150$ & 180.7 & 0.708788 & 0.000016 & & & -0.58 & \\
\hline $28 X-4,140-150$ & 262.2 & 0.708590 & 0.000013 & & & & \\
\hline $30 X-1,140-150$ & 277.0 & & & & & -0.65 & \\
\hline $33 X-4,115-120$ & 310.2 & 0.708377 & 0.000014 & & & & \\
\hline $38 X-4,140-150$ & 352.5 & & & & & -0.62 & \\
\hline \multicolumn{8}{|l|}{ 180-1109D- } \\
\hline 4R-3, 96-106 & 381.6 & 0.708368 & 0.000013 & & & & \\
\hline $11 \mathrm{R}-3,122-132$ & 449.3 & 0.708420 & 0.000014 & & & -0.71 & \\
\hline $20 \mathrm{R}-3,65-75$ & 535.4 & 0.708660 & 0.000013 & & & -0.75 & \\
\hline $26 \mathrm{R}-3,30-40$ & 583.0 & 0.708850 & 0.000016 & & & -0.82 & \\
\hline $29 R-2,93-103$ & 610.9 & & & & & -0.77 & \\
\hline $34 \mathrm{R}-3,123-133$ & 661.0 & 0.708856 & 0.000014 & & & -0.73 & \\
\hline $36 \mathrm{R}-2,140-150$ & 679.3 & & & & & -0.83 & \\
\hline $38 R-4,140-150$ & 701.2 & 0.708708 & 0.000014 & & & -0.84 & \\
\hline $40 \mathrm{R}-2,29-39$ & 716.6 & & & & & -0.97 & \\
\hline $43 R-2,82-89$ & 745.7 & 0.708179 & 0.000014 & & & -1.27 & \\
\hline \multicolumn{8}{|l|}{$180-115 A-$} \\
\hline $1 \mathrm{H}-1,23-28$ & 0.2 & 0.709159 & 0.000014 & & & -0.09 & \\
\hline $1 \mathrm{H}-4,115-120$ & 4.2 & & & & & -0.01 & \\
\hline \multicolumn{8}{|l|}{ 180-1115B- } \\
\hline $3 \mathrm{H}-3,145-150$ & 21.2 & & & & & 0.23 & 0.24 \\
\hline $5 \mathrm{H}-1,145-150$ & 37.2 & & & & & 0.29 & \\
\hline $7 \mathrm{H}-1,145-150$ & 56.2 & 0.709057 & 0.000017 & & & 0.08 & 0.25 \\
\hline $10 \mathrm{H}-3,145-150$ & 87.7 & & & & & 0.01 & \\
\hline $13 \mathrm{H}-1,145-150$ & 113.2 & & & & & -0.15 & \\
\hline $17 \mathrm{H}-1,145-150$ & 151.2 & 0.708832 & 0.000014 & & & -0.28 & \\
\hline $23 \mathrm{H}-1,145-150$ & 208.2 & & & & & -0.52 & -0.48 \\
\hline $25 X-1,145-150$ & 227.3 & & & & & -0.55 & \\
\hline $27 X-1,145-150$ & 246.5 & & & & & -0.61 & \\
\hline $29 X-1,145-150$ & 265.8 & 0.708418 & 0.000014 & 0.708443 & 0.000014 & -0.67 & \\
\hline \multicolumn{8}{|l|}{ 180-1115C- } \\
\hline 2R-1, 144-150 & 294.2 & & & & & -0.77 & -0.66 \\
\hline 7R-1, 141-146 & 342.4 & & & & & -0.78 & \\
\hline $12 \mathrm{R}-3,130-140$ & 392.8 & 0.708506 & 0.000013 & & & -0.95 & \\
\hline 17R-1, 109-119 & 437.6 & & & & & -1.18 & -1.13 \\
\hline $22 \mathrm{R}-1,140-150$ & 485.9 & & & & & -1.21 & \\
\hline $25 R-1,140-150$ & 514.8 & 0.708108 & 0.000016 & & & -1.28 & -1.16 \\
\hline $28 \mathrm{R}-1,20-30$ & 542.4 & 0.707998 & 0.000016 & & & -1.31 & \\
\hline $32 \mathrm{R}-3,116-126$ & 584.1 & 0.707343 & 0.000014 & & & -1.88 & \\
\hline $34 \mathrm{R}-1,138-148$ & 601.2 & 0.707143 & 0.000013 & & & -2.32 & \\
\hline $40 \mathrm{R}-2,140-150$ & 660.7 & & & & & -2.84 & \\
\hline $42 \mathrm{R}-3,140-150$ & 680.8 & 0.707388 & 0.000014 & & & -2.72 & -2.67 \\
\hline $46 \mathrm{R}-1,105-115$ & 716.8 & 0.707841 & 0.000013 & & & -2.6 & -2.72 \\
\hline 50R-5, 90-102 & 760.1 & 0.707915 & 0.000016 & & & & \\
\hline $54 R-4,140-150$ & 798.1 & 0.707949 & 0.000014 & & & & \\
\hline \multicolumn{8}{|l|}{ 180-1118A- } \\
\hline $6 R-4,140-150$ & 257.8 & 0.708525 & 0.000014 & & & -0.36 & -0.54 \\
\hline $8 R-4,140-150$ & 278.0 & & & & & -0.54 & \\
\hline $10 \mathrm{R}-2,140-150$ & 294.3 & & & & & -0.61 & \\
\hline $12 \mathrm{R}-3,111-121$ & 314.3 & & & & & -0.79 & \\
\hline 14R-4, 131-141 & 335.1 & & & & & -0.96 & \\
\hline 16R-5, 91-101 & 355.9 & 0.707910 & 0.000016 & & & -1.13 & \\
\hline $18 \mathrm{R}-2,128-137$ & 371.0 & & & & & -1.28 & \\
\hline 20R-6, 134-146 & 395.8 & & & & & -1.4 & \\
\hline $22 \mathrm{R}-5,112-123$ & 413.1 & & & & & -1.35 & -1.4 \\
\hline 24R-1, 134-146 & 426.9 & & & & & -1.45 & \\
\hline 26R-3, 110-119 & 448.9 & 0.707642 & 0.000016 & & & -1.51 & \\
\hline
\end{tabular}


E.H. De CARLo et AL.

DATA REPORT: COMPOSITION OF INTERSTITIAL WATER

Table T2 (continued).

\begin{tabular}{|c|c|c|c|c|c|c|c|}
\hline $\begin{array}{l}\text { Core, section, } \\
\text { interval }(\mathrm{cm})\end{array}$ & $\begin{array}{l}\text { Depth } \\
\text { (mbsf) }\end{array}$ & ${ }^{87} \mathrm{Sr} /{ }^{86} \mathrm{Sr}$ & $\begin{array}{c}2-\sigma \\
\text { uncertainty }\end{array}$ & $\begin{array}{l}\text { Replicate } \\
{ }^{87} \mathrm{Sr} /{ }^{86} \mathrm{Sr}\end{array}$ & $\begin{array}{c}2-\sigma \\
\text { uncertainty }\end{array}$ & $\delta^{18} \mathrm{O}$ & $\begin{array}{c}\text { Replicate } \\
\delta^{18} \mathrm{O}\end{array}$ \\
\hline 28R-4, 107-117 & 469.4 & & & & & -1.55 & \\
\hline $30 \mathrm{R}-2,132-142$ & 486.0 & & & & & -1.58 & \\
\hline 32R-2, 131-141 & 505.3 & & & & & -1.6 & -1.61 \\
\hline 34R-3, 116-131 & 525.7 & 0.707370 & 0.000017 & 0.707385 & 0.000017 & -1.61 & \\
\hline $36 \mathrm{R}-2,135-145$ & 543.5 & 0.707397 & 0.000014 & & & -1.63 & \\
\hline 39R-1, 138-150 & 571.4 & & & & & -1.54 & \\
\hline $42 R-4,98-110$ & 603.6 & 0.707487 & 0.000014 & & & -1.44 & \\
\hline $45 R-6,92-102$ & 634.6 & 0.707604 & 0.000014 & & & -1.25 & \\
\hline $48 \mathrm{R}-3,112-122$ & 660.4 & & & & & -1.09 & \\
\hline $51 \mathrm{R}-1,74-89$ & 686.0 & 0.708024 & 0.000014 & & & -1.01 & \\
\hline $55 R-1,72-87$ & 724.8 & & & & & -0.91 & \\
\hline 58R-4, 135-150 & 758.2 & 0.708238 & 0.000013 & & & -0.86 & \\
\hline $61 \mathrm{R}-1,113-128$ & 783.0 & & & & & -0.87 & \\
\hline $64 R-1,9-21$ & 810.8 & & & & & -0.93 & \\
\hline 67R-2, 135-150 & 842.2 & 0.708521 & 0.000016 & & & -1.09 & \\
\hline
\end{tabular}


Table T3. Trace element composition of clays isolated from interstitial water squeeze-cake samples, Site 1109.

\begin{tabular}{|c|c|c|c|c|c|c|c|c|c|c|c|c|c|c|c|c|c|c|}
\hline $\begin{array}{l}\text { Core, section, } \\
\text { interval }(\mathrm{cm})\end{array}$ & $\begin{array}{l}\text { Depth } \\
\text { (mbsf) }\end{array}$ & $\begin{array}{c}\mathrm{Rb} \\
(\mu \mathrm{g} / \mathrm{g})\end{array}$ & $\begin{array}{c}\mathrm{Ba} \\
(\mu \mathrm{g} / \mathrm{g})\end{array}$ & $\begin{array}{c}\mathrm{Nb} \\
(\mu \mathrm{g} / \mathrm{g})\end{array}$ & $\begin{array}{c}\mathrm{La} \\
(\mu \mathrm{g} / \mathrm{g})\end{array}$ & $\begin{array}{c}\mathrm{Ce} \\
(\mu \mathrm{g} / \mathrm{g})\end{array}$ & $\begin{array}{c}\operatorname{Pr} \\
(\mu \mathrm{g} / \mathrm{g})\end{array}$ & $\begin{array}{c}\mathrm{Pb} \\
(\mu \mathrm{g} / \mathrm{g})\end{array}$ & $\begin{array}{c}\mathrm{Nd} \\
(\mu \mathrm{g} / \mathrm{g})\end{array}$ & $\begin{array}{c}\mathrm{Sr} \\
(\mu \mathrm{g} / \mathrm{g})\end{array}$ & $\underset{(\mu \mathrm{g} / \mathrm{g})}{\mathrm{Sm}}$ & $\begin{array}{c}\mathrm{Zr} \\
(\mu \mathrm{g} / \mathrm{g})\end{array}$ & $\begin{array}{c}\mathrm{Ti} \\
(\mu \mathrm{g} / \mathrm{g})\end{array}$ & $\begin{array}{c}E u \\
(\mu \mathrm{g} / \mathrm{g})\end{array}$ & $\begin{array}{l}\text { Gd } \\
(\mu \mathrm{g} / \mathrm{g})\end{array}$ & $\begin{array}{c}Y \\
(\mu \mathrm{g} / \mathrm{g})\end{array}$ & $\begin{array}{c}\mathrm{Yb} \\
(\mu \mathrm{g} / \mathrm{g})\end{array}$ & $\begin{array}{c}\mathrm{Hf} \\
(\mu \mathrm{g} / \mathrm{g})\end{array}$ \\
\hline \multicolumn{19}{|l|}{ 180-1109B- } \\
\hline $1 \mathrm{H}-2,145-150$ & 2.9 & 62.0 & 1190 & 7.9 & 19.5 & 29.0 & 4.6 & 27.2 & 18.4 & 205 & 3.9 & 123 & 6779 & 1.3 & 4.4 & 31.1 & 2.8 & 7.7 \\
\hline $2 \mathrm{H}-3,145-150$ & 9.8 & 61.5 & 1016 & 5.1 & 20.9 & 37.6 & 5.3 & 18.2 & 21.0 & 220 & 4.5 & 73 & 6394 & 2.1 & 5.5 & 29.4 & 3.0 & \\
\hline \multicolumn{19}{|l|}{ 180-1109C- } \\
\hline $5 \mathrm{H}-3,145-150$ & 40.4 & 53.4 & 808 & 4.1 & 15.0 & 24.5 & 3.8 & 14.6 & 15.5 & 275 & 3.5 & 40 & 7759 & 1.9 & 4.4 & 27.6 & 2.4 & \\
\hline $6 \mathrm{H}-3,145-150$ & 49.9 & 70.1 & 534 & 14.6 & 24.7 & 51.0 & 6.4 & 27.4 & 24.4 & 150 & 5.3 & 296 & 6767 & 1.0 & 5.5 & 34.2 & 3.3 & 18.2 \\
\hline $8 \mathrm{H}-3,145-150$ & 68.9 & 42.0 & 533 & 3.9 & 17.3 & 37.0 & 4.7 & 26.2 & 18.4 & 360 & 3.9 & 65 & 7407 & 1.6 & 4.3 & 20.4 & 1.9 & \\
\hline $10 \mathrm{H}-4,115-120$ & 89.1 & 46.7 & 360 & 3.8 & 16.7 & 35.3 & 4.4 & 25.5 & 16.6 & 278 & 3.6 & 51 & 6278 & 1.2 & 3.2 & 14.9 & 1.5 & \\
\hline $11 \mathrm{H}-3,145-150$ & 97.4 & 51.9 & 361 & 4.0 & 15.4 & 37.3 & 4.3 & 23.5 & 16.1 & 304 & 3.5 & 62 & 4743 & 1.0 & 3.3 & 14.9 & 1.4 & \\
\hline $14 X-3,145-150$ & 126.1 & 39.3 & 417 & 3.6 & 16.3 & 34.2 & 4.5 & 33.3 & 17.3 & 311 & 3.8 & 49 & 5587 & 1.4 & 4.3 & 13.5 & 1.4 & \\
\hline $16 \mathrm{X}-3,145-150$ & 145.3 & 49.6 & 470 & 4.3 & 17.4 & 37.0 & 4.8 & 32.4 & 17.5 & 303 & 3.4 & 65 & 4749 & 1.3 & 4.4 & 13.4 & 1.4 & \\
\hline $18 X-3,115-120$ & 164.3 & 46.6 & 328 & 6.6 & 12.4 & 23.9 & 3.1 & 34.0 & 11.9 & 172 & 2.5 & 129 & 5558 & 0.7 & 2.3 & 11.8 & 1.2 & 7.9 \\
\hline $23 X-4,33-43$ & 212.4 & 42.3 & 526 & 2.8 & 11.1 & 24.6 & 3.2 & 24.6 & 12.8 & 380 & 2.9 & 38 & 5606 & 1.4 & 3.4 & 11.7 & 1.2 & \\
\hline $23 \mathrm{X}-4,33-43$ & 212.4 & 41.4 & 532 & 2.9 & 13.1 & 28.1 & 3.6 & 22.9 & 13.8 & 382 & 2.9 & 40 & 6203 & 1.3 & 2.9 & 12.5 & 1.1 & \\
\hline $26 \mathrm{X}-1,140-145$ & 238.4 & 29.8 & 149 & 3.8 & 9.7 & 20.2 & 2.5 & 27.2 & 9.6 & 151 & 1.9 & 94 & 4071 & 0.5 & 1.8 & 7.5 & 0.7 & 5.7 \\
\hline $32 X-3,140-150$ & 299.2 & 39.4 & 392 & 2.8 & 16.4 & 35.4 & 4.4 & 20.3 & 16.3 & 416 & 3.4 & 56 & 5457 & 1.3 & 4.1 & 13.7 & 1.3 & \\
\hline $32 X-3,140-150$ & 299.2 & 38.8 & 380 & 2.8 & 16.0 & 34.5 & 4.1 & 19.7 & 14.8 & 390 & 2.7 & 59 & 5689 & 1.1 & 3.1 & 12.2 & 1.1 & \\
\hline $35 X-3,140-150$ & 328.3 & 32.6 & 124 & 3.3 & 9.3 & 19.5 & 2.4 & 11.3 & 9.4 & 147 & 1.9 & 124 & 4200 & 0.5 & 1.8 & 8.5 & 0.8 & 8.0 \\
\hline $39 X-3,140-150$ & 357.0 & 50.4 & 635 & 2.9 & 12.4 & 25.2 & 3.1 & 21.4 & 11.5 & 394 & 2.1 & 44 & 6712 & 1.3 & 2.9 & 9.9 & 1.0 & \\
\hline $41 X-2,140-150$ & 374.4 & 31.3 & 384 & 2.9 & 11.0 & 30.3 & 3.2 & 23.3 & 11.8 & 409 & 2.5 & 49 & 5927 & 1.1 & 2.5 & 11.5 & 1.2 & \\
\hline \multicolumn{19}{|l|}{ 180-1109D- } \\
\hline $7 R-3,120-130$ & 410.7 & 56.0 & 584 & 3.0 & 13.8 & 27.8 & 3.5 & 24.3 & 13.1 & 423 & 2.5 & 39 & 5664 & 1.2 & 2.9 & 9.6 & 1.0 & \\
\hline $11 \mathrm{R}-3,122-132$ & 449.3 & 45.9 & 283 & 4.6 & 14.9 & 32.4 & 3.7 & 22.1 & 13.8 & 185 & 2.7 & 110 & 5827 & 0.8 & 2.5 & 10.5 & 1.0 & 7.3 \\
\hline $13 \mathrm{R}-3,79-89$ & 467.9 & 42.4 & 249 & 4.6 & 12.8 & 28.3 & 3.2 & 21.6 & 12.3 & 175 & 2.5 & 109 & 5417 & 0.7 & 2.2 & 9.9 & 0.9 & 7.6 \\
\hline $18 R-4,120-130$ & 517.7 & 76.2 & 737 & 3.0 & 13.4 & 30.1 & 3.7 & 31.4 & 14.3 & 647 & 2.7 & 39 & 5883 & 1.5 & 3.2 & 10.9 & 1.1 & \\
\hline $26 \mathrm{R}-3,30-40$ & 583.0 & 34.9 & 118 & 3.4 & 7.7 & 16.6 & 2.2 & 12.8 & 8.9 & 281 & 1.9 & 107 & 4961 & 0.6 & 1.9 & 8.3 & 0.8 & 7.5 \\
\hline $29 \mathrm{R}-2,93-103$ & 610.9 & 46.0 & 620 & 3.1 & 17.7 & 36.2 & 5.2 & 31.6 & 20.0 & 940 & 3.8 & 29 & 5993 & 1.6 & 4.1 & 8.3 & 0.7 & \\
\hline $29 \mathrm{R}-2,93-103$ & 610.9 & 54.7 & 692 & 3.1 & 20.4 & 44.3 & 5.7 & 32.4 & 21.5 & 976 & 4.2 & 35 & 6011 & 1.8 & 4.1 & 9.7 & 1.0 & \\
\hline $34 \mathrm{R}-3,123-133$ & 661.0 & 14.1 & 80 & 2.8 & 5.1 & 10.7 & 1.5 & 7.3 & 6.3 & 130 & 1.5 & 96 & 6175 & 0.4 & 1.4 & 6.7 & 0.6 & 6.2 \\
\hline $38 \mathrm{R}-4,140-150$ & 701.2 & 19.2 & 215 & 5.9 & 23.4 & 53.3 & 7.2 & 14.0 & 30.1 & 263 & 7.3 & 100 & 10961 & 2.0 & 7.9 & 40.7 & 3.5 & 8.8 \\
\hline
\end{tabular}


E.H. DE CARLo et AL.

DATA REPORT: Composition OF INTERSTITIAL WATER

Table T4. Mineralogical assemblages of the clay fraction of sediments, Holes 1109B, 1109C, and 1109D.

\begin{tabular}{|c|c|c|c|c|c|c|c|c|c|c|c|c|}
\hline $\begin{array}{l}\text { Core, section, } \\
\text { interval }(\mathrm{cm})\end{array}$ & $\begin{array}{l}\text { Depth } \\
\text { (mbsf) }\end{array}$ & Quartz & Feldspar & Pyrite & Magnesite & Clinoptinolite & Illite & Talc & Serpentine & Smectite & $\mathrm{C} / \mathrm{S}$ & Chlorite \\
\hline \multicolumn{13}{|l|}{ 180-1109B- } \\
\hline $1 \mathrm{H}-2,145-150$ & 2.9 & $x x$ & $\mathrm{x}$ & & & & $x$ & & & $x x$ & & $x x$ \\
\hline $2 \mathrm{H}-3,145-150$ & 9.8 & $x x$ & $\mathrm{x}$ & & & & $x$ & & & & $x x$ & $x x$ \\
\hline $2 \mathrm{H}-5,145-150$ & 12.1 & $x x$ & $\mathrm{x}$ & $\mathrm{x}$ & & & $x$ & & & $x x$ & & $x x$ \\
\hline \multicolumn{13}{|l|}{ 180-1109C- } \\
\hline $3 \mathrm{H}-2,145-150$ & 19.9 & $x x$ & $\mathrm{x}$ & * & & & $x$ & & & & & $x x$ \\
\hline $5 \mathrm{H}-3,145-150$ & 40.4 & $x x$ & $x(P)$ & & & & $x$ & & & $x x$ & & $x x$ \\
\hline $6 \mathrm{H}-3,145-150$ & 49.9 & $x x$ & $x(P)$ & & & & $x$ & & & & $x x$ & $x x$ \\
\hline $8 \mathrm{H}-3,145-150$ & 68.9 & $x x$ & $x(P)$ & & & & * & & & $x x$ & & $x x$ \\
\hline $10 \mathrm{H}-4,115-120$ & 89.1 & $x x$ & $x$ & & & & * & $x x$ & $x x$ & & $x x$ & $x x$ \\
\hline $11 \mathrm{H}-3,145-150$ & 97.0 & $x x$ & $\mathrm{x}$ & & * & & * & $x x$ & $x x$ & & $x x$ & $x x$ \\
\hline $14 \mathrm{X}-3,145-150$ & 126.1 & $x x$ & $x$ & * & & & * & $x x$ & $x x$ & $x x$ & & $x x$ \\
\hline $16 \mathrm{X}-3,145-150$ & 145.3 & $x x$ & $\mathrm{x}$ & & & & * & $x x$ & $x x$ & $x x$ & & $x x$ \\
\hline $18 X-3,115-120$ & 164.3 & $x x$ & $\mathrm{x}$ & * & & & * & $x x$ & $x x$ & $x x x$ & $x x$ & \\
\hline $23 X-3,33-43$ & 212.4 & $x x$ & $x$ & & & & * & $x x$ & $x x$ & $x x$ & & $x x$ \\
\hline $26 \mathrm{X}-1,140-145$ & 238.4 & $x$ & $x$ & & $\mathrm{x}$ & & & $x x$ & $x x$ & $x x$ & & $x x$ \\
\hline $29 X-3,140-150$ & 270.4 & $\mathrm{x}$ & $x x(P)$ & * & & & * & & & $x x$ & & $x x$ \\
\hline $32 X-3,140-150$ & 299.2 & $x x$ & $x$ & & & & * & & & $x x$ & & $x x x$ \\
\hline \multicolumn{13}{|l|}{ 180-1109D- } \\
\hline $35 X-3,140-150$ & 328.3 & $x x$ & $x$ & & & & * & & & $x x x$ & & $x$ \\
\hline \multicolumn{13}{|l|}{ 180-1109C- } \\
\hline $39 X-3,140-150$ & 357.0 & $x$ & $x$ & & & $x x$ & * & & & $x x x$ & & $x$ \\
\hline $41 X-2,140-150$ & 374.4 & $x x$ & $x$ & & & & * & & & $x x$ & & $x$ \\
\hline \multicolumn{13}{|l|}{ 180-1109D- } \\
\hline $7 R-3,120-130$ & 410.7 & $x x$ & $\mathrm{x}$ & & & & * & & & $x x$ & & $\mathrm{x}$ \\
\hline $9 \mathrm{R}-3,101-111$ & 430.1 & $x x$ & $x x$ & & & & $x$ & & & & $x x$ & $x x$ \\
\hline 11R-3, 122-132 & 449.3 & $x x$ & $x x$ & & & & * & & & & $x x$ & $x x$ \\
\hline $13 \mathrm{R}-3,79-89$ & 467.9 & $x x$ & $x$ & * & & & * & & & $x x x$ & & $x$ \\
\hline 16R-5, 120-130 & & $x x$ & $\mathrm{x}$ & * & & & * & & & & & $x x x$ \\
\hline $18 \mathrm{R}-4,120-130$ & 517.7 & $x x$ & $x$ & & & & $x$ & & & $x x$ & & $\mathrm{x}$ \\
\hline 22R-1, 124-134 & 552.4 & * & * & & & $x x$ & * & & & $x x$ & & $\mathrm{x}$ \\
\hline $26 \mathrm{R}-3,30-40$ & 583.0 & $x x$ & $\mathrm{x}$ & & & & * & & & $x x x$ & & $\mathrm{x}$ \\
\hline $29 \mathrm{R}-2,93-103$ & 610.9 & $x x$ & $x x(P)$ & $\mathrm{x}$ & & & * & & & $x x$ & & $x x$ \\
\hline $34 \mathrm{R}-3,123-133$ & 661.0 & $\mathrm{x}$ & * & & & & * & & & $x x x$ & & $x ?$ \\
\hline $38 \mathrm{R}-4,150-150$ & 701.4 & $x x$ & $x$ & & & & * & $x$ & & $x x x$ & & $x$ \\
\hline
\end{tabular}

Notes: Assemblages were determined by $X$-ray diffraction analyses. $C / S=$ chlorite-smectite mixed-layer, $(P)=$ including feldspar. $x x x=$ abundant, $x x=$ common, $x=$ rare, ${ }^{*}=$ trace. 